\title{
Short incubation non-A, non-B hepatitis transmitted by factor VIII concentrates in patients with congenital coagulation disorders
}

\author{
M B A M B R, A MURRAY, B A M ARBORGH*, P J SCHEUER, \\ P B A KERNOFF, H C THOMAS, S SHERLOCK \\ From the Departments of Medicine, Histopathology and Haematology, Royal Free Hospital, London
}

SUMmARY Ten cases are reported of short incubation (one to four weeks) non-A, non-B hepatitis occurring after infusion of various preparations of factor VIII concentrates into patients with coagulation disorders. Five patients were symptomatic and, in all, serum transaminase levels were increased for at least six months. These cases of chronic hepatitis exhibited none of the features of autoimmune chronic hepatitis: autoantibodies were negative and serum immunoglobulins were normal. Hepatic histology confirmed acute hepatitis in two cases biopsied early in the illness, and chronic active hepatitis (three) or chronic persistent hepatitis (two) in five cases studied later. Lobular inflammation was a prominent feature in all cases. Other features not commonly associated with type A or B hepatitis included fatty change and damaged bile ducts.

Patients with congenital coagulation disorders receive large quantities of blood derivatives and acute hepatitis is not an uncommon occurrence. The development of serological techniques to identify acute type A and B hepatitis has led to the conclusion that additional hepatitis viruses exist. ${ }^{2}$ These have been provisionally designated the non-A, non-B hepatitis viruses.

There is evidence of more than one type of non-A, non-B virus. A drug addict suffered four attacks of hepatitis, one proven type $A$, another type B, and, in addition, two other episodes. ${ }^{3}$ Chimpanzees, after factor IX injections, have developed non-A, non-B hepatitis with an incubation period of 10 weeks, to be followed by hepatitis 10 to 14 days after infusion of factor VIII. ${ }^{4}$ In chimpanzees, electron microscopy has shown two cytologically distinct non-A, non-B hepatitises, one with cytoplasmic and the other with nuclear changes. ${ }^{67}$

The antigen characteristics of these non-A, non-B viruses have not been adequately elucidated. Shirachi et al. ${ }^{8}$ described an antigen/anti-

*Dr Arborgh died before this paper was published.

Received for publication 2 April 1981 body system predominantly associated with acute hepatitis with an incubation period of seven to eight weeks. More recently, Vitvitski et al. ${ }^{9}$ have described an antigen/antibody system in patients with non-A, non-B hepatitis with an incubation period of six to 14 weeks. However, there is still no agreement on the specificity of the various immunodiffusion systems, as Suh et al. have recently suggested. ${ }^{10}$

In this paper we report the clinical, biochemical, immunological, and histological aspects of short (one to four weeks) incubation hepatitis in 10 patients with coagulation disorders who had received either National Health Service (NHS) or commercial factor VIII concentrate or cryoprecipitate.

\section{Methods}

Eight patients with haemophilia and two with Von Willebrand's disease (patients 1,9$)$ developed abnormal serum transaminase levels $\left(>2 \frac{1}{2}\right.$ times the upper limit of normal) one to four weeks after receiving factor VIII concentrate or cryoprecipitate. In five of these cases no additional infusion had been administered in the previous 12 weeks, and four of these were receiving a commercial 
concentrate for the first time. The other five patients who also developed hepatitis one to four weeks after their last factor VIII infusion, had received other infusions within the previous eight weeks (Table 1). In these patients the infusion responsible for transmission could not be established. The previous infusion history is also summarised in Table 1. All patients were followed up at one to three weekly intervals for more than six months. Serum aspartate transaminase, alkaline phosphatase and bilirubin levels were normal before the last infusion before the onset of hepatitis. Acute and chronic phase sera were examined for evidence of hepatitis A; hepatitis B, cytomegalovirus, Epstein-Barr virus, rubella, measles, and herpes simplex. Acute hepatitis A infection was excluded if acute phase sera were negative for IgM antibody to hepatitis A virus (IgM antihepatitis A virus). IgM antihepatitis A virus was measured by a modified radioimmunoassay (HAVAB, Abbott Laboratories) test. ${ }^{11} \mathrm{IgM}$ and IgG antihepatitis $A$ virus were differentiated by assaying sera for antihepatitis A antibody before and after absorption of IgG with staphylococcal protein A. Acute hepatitis B virus infection was excluded if hepatitis B surface antigen ( $\mathrm{HBsAg}$ ), tested by radioimmunoassay (AUSRIA) was negative or if antibody to hepatitis B core antigen $(\mathrm{HBcAb})$, as measured by radioimmunoassay (CORAB) was negative. The presence of both $\mathrm{HBcAb}$ and antibody to $\mathrm{HBsAg}$ (HBsAb) signified past infection and recovery from hepatitis $B$ virus infection. These patients were included. EpsteinBarr virus infection was diagnosed by an immunofluorescent test, and cytomegalovirus, rubella, measles, and herpes simplex by complement fix-

Table 1 Exposure to factor VIII infusions

\begin{tabular}{clcl}
\hline No. & \multicolumn{2}{l}{$\begin{array}{l}\text { Interval (weeks) to onset of abnormal } \\
\text { LFTs }\end{array}$} & $\begin{array}{l}\text { Previous infusion } \\
\text { requirements }\end{array}$ \\
\cline { 2 - 3 } & From last infusion & $\begin{array}{l}\text { From 2nd last } \\
\text { infusion }\end{array}$ & \\
\hline 1 & 1 (Conc)* & 13 (Cryo) & 6 monthly (Cryo) \\
2 & $21 \frac{1}{2}$ (Cryo) & 41 (Cryo) & Monthly (Cryo) \\
3 & 3 (Conc) & 8 (Cryo+Conc) & Monthly (Cryo) \\
4 & $2 \frac{1}{1}$ (Conc) & $16 \frac{1}{2}$ (Conc) & Monthly (Cryo) \\
5 & 4 (Conc)* & 10 years (Cryo) & None \\
6 & 3 (Conc)* & 7 (Cryo) & Monthly (Cryo) \\
7 & 4 (Conc)* & 16 (Cryo) & 6 monthly (Cryo) \\
8 & 1 (Conc) & 5 (Conc) & 3 weekly (Conc) \\
9 & 3 (Conc)* & 19 (Cryo) & 2 weekly (Cryo) \\
10 & 4 (Cryo) & 5 (Cryo) & Weekly (Cryo) \\
\hline
\end{tabular}

Conc: factor VIII concentrate. Cryo: cryoprecipitate. *Received for the first time, LFTs: liver function tests. ation tests. Autoantibodies were measured by indirect immunofluorescence using rat liver and kidney as substrate, and serum immunoglobulin by radial immunodiffusion.

Seven patients underwent needle biopsy at varying times after onset of the hepatitis. This material was examined by light microscopy and by indirect and direct immunofluorescence for the presence of hepatitis B virus antigens (HBs and $\mathrm{HBc}$ ). Fluorescein isothiocyanate (FITC) labelled human anti-HBc was used in a direct staining system, whereas rabbit anti-HBs was used with FITC labelled antiglobulin in an indirect system. Positive control liver was used for $\mathrm{HBc}$ and $\mathrm{HBs}$ antigens.

\section{Results}

C L I N I CA L F E A T U R E S

Acute hepatitis was seen after infusion of cryoprecipitate, commercial and NHS factor VIII concentrates. In the five patients receiving a single infusion in the three months before the hepatitis, the incubation period (time from infusion to first documented abnormal transaminase) was from one to four weeks. In the remaining five cases the infusate responsible for transmission of the infection could not be established with certainty, although the interval between the last infusion and the onset of raised transaminase was also one to four weeks.

Five patients had symptoms (Table 2). They complained of lethargy, nausea (rarely vomiting), abdominal discomfort, and icterus. In one patient these symptoms were severe and persistent and eventually, seven months after the onset, necessitated steroid therapy.

Six or more months after the beginning of the illness, four patients had mild splenomegaly but oesophageal varices could not be demonstrated radiologically.

\section{I V E R F U N C T I O N T E S T S}

The rise in peak transaminase was usually within the first month, ranging from 139-1095 IU/1 (normal $<15 \mathrm{IU} / \mathrm{l})$. The transaminase levels then fluctuated rapidly, changing from levels higher than $300 \mathrm{IU} / 1$ to normal levels over a period of one to two weeks (Fig. 1). Although the general trend was towards a reduction of peak levels during the course of the disease, all patients still had abnormal levels at six or more months. The pattern of transaminase abnormality was similar in patients receiving single and multiple infusions of concentrate. 
Table 2 Clinical data

\begin{tabular}{|c|c|c|c|c|c|c|c|}
\hline \multirow[t]{2}{*}{ Patient } & \multirow{2}{*}{$\begin{array}{l}\text { Age } \\
(y r)\end{array}$} & \multirow[t]{2}{*}{$\operatorname{Sex}$} & \multirow[t]{2}{*}{ Clinical details } & \multicolumn{3}{|l|}{ Peak } & \multirow{2}{*}{$\begin{array}{l}\text { Duration of } \\
\text { abnormal LFTs } \\
\text { (months) }\end{array}$} \\
\hline & & & & $A S T$ & $A P$ & $B I L$ & \\
\hline 1 & 30 & $\mathbf{F}$ & Jaundice & 346 & 63 & 254 & 6 \\
\hline 2 & 21 & $\mathbf{M}$ & $\begin{array}{l}\text { Jaundice } \\
\text { Malaise }\end{array}$ & 216 & 12 & 90 & 61 \\
\hline 3 & 58 & $\mathbf{M}$ & Malaise & 1095 & 22 & 269 & 8 \\
\hline 4 & 42 & $\mathbf{M}$ & Asymptomatic & 153 & 13 & 20 & 10 \\
\hline 5 & 78 & $\mathbf{M}$ & Jaundice & 139 & 28 & 268 & 11 \\
\hline 6 & 30 & $\mathbf{M}$ & Jaundice & 300 & 19 & 84 & 12 \\
\hline 7 & 13 & $\mathbf{M}$ & Asymptomatic & 384 & 41 & 18 & 12 \\
\hline 8 & 8 & $\mathbf{M}$ & Asymptomatic & 281 & 20 & 29 & 12 \\
\hline 9 & 19 & $\mathbf{M}$ & Asymptomatic & 457 & 25 & 25 & 35 \\
\hline 10 & 18 & $\mathbf{M}$ & Asymptomatic & 271 & 27 & 23 & 45 \\
\hline
\end{tabular}

AST: A separate transaminase in IU/1.

AP: Alkaline phosphatase in King Armstrong (KA) units $/ 100 \mathrm{ml}$ (upper limit =13) $1 \mathrm{KA}$ unit $=7$ international units.

Bil: Bilirubin in $\mu \mathrm{mol} / \mathrm{l}$ (upper limit 17).

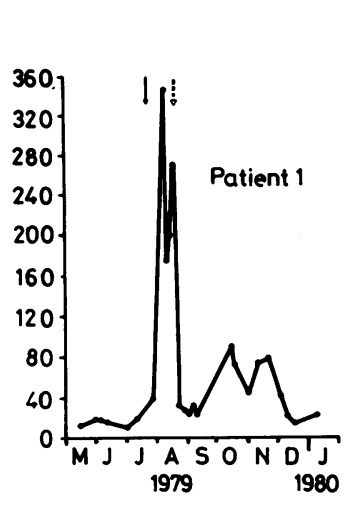

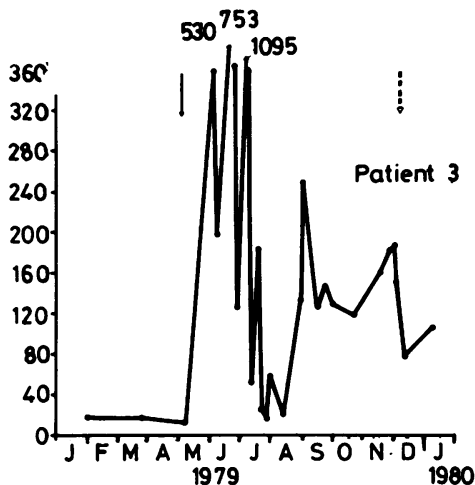

Ag was present in July 1978

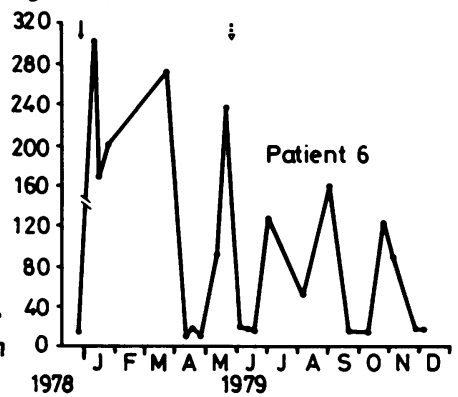

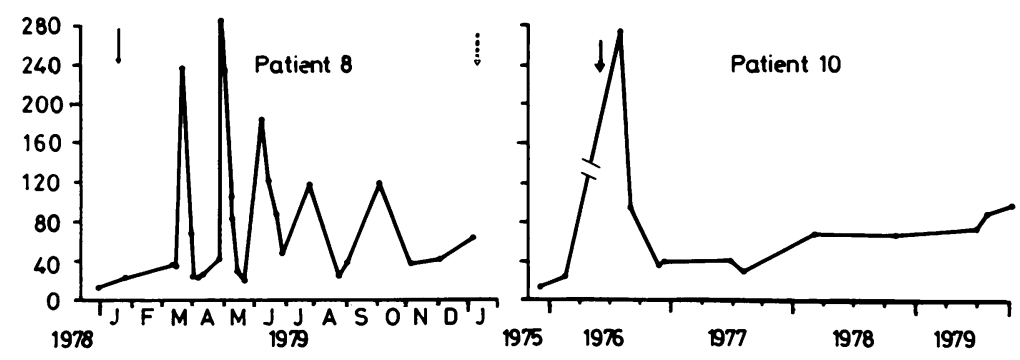

Fig. 1 Serial observations of aspartate transaminase levels $(I U / l)$ in patients $2,3,5,6,8$, and 10. Arrow: infusions of factor VIII concentrate or cryoprecipitate. Dotted arrow: time of liver biopsy. 
Serum IgM, IgG and IgA levels were always normal.

One patient (patient 1 ) showed a transient positive $(1 / 40)$ antinuclear factor. Another (patient 5) had smooth muscle antibody higher than 1/40 transiently. Autoantibodies were not detected at six months.

\section{S E R O L O G Y}

During the acute phase, four patients were negative for antibody to hepatitis A virus. Seven were positive but none had IgM anti-hepatitis A virus. All patients were negative for HBs antigen by radioimmunoassay: seven had antibody to both HBs and $\mathrm{HBc}$ from the onset and throughout the hepatitis and the remainder were negative for both antibodies throughout.

There was no change in titre of antibody to Epstein-Barr virus, cytomegalovirus, herpes simplex, measles, and rubella between acute and later sera.

\section{H I S T O L O G Y}

Light microscopy (Table 3)

The acute hepatitis in patient 1 (Fig. 2) was histologically mild, and characterised by centrilobular liver-cell swelling, fatty change, and both canalicular and intracellular cholestasis. Swollen cells had unusually large nucleoli. A few acidophilic bodies and liver-cell mitoses were seen. Kupffer cells were enlarged and PAS-positive, and some stained for iron. The mixed inflammatory infiltrate, composed of lymphocytes, plasma cells, and segmented leucocytes was sparse. There was no bridging necrosis. An operative liver biopsy taken at laparotomy three months earlier had shown a few inflammatory cells in portal tracts and sinusoids, but no evidence of liver-cell damage.
Both biopsies taken at three to six months (patients 6 and 7) showed, in addition to focal liver-cell damage and focal thickening of liver-cell plates, a heavy infiltration by mononuclear cells. In the biopsy of patient 6 the abundant portal

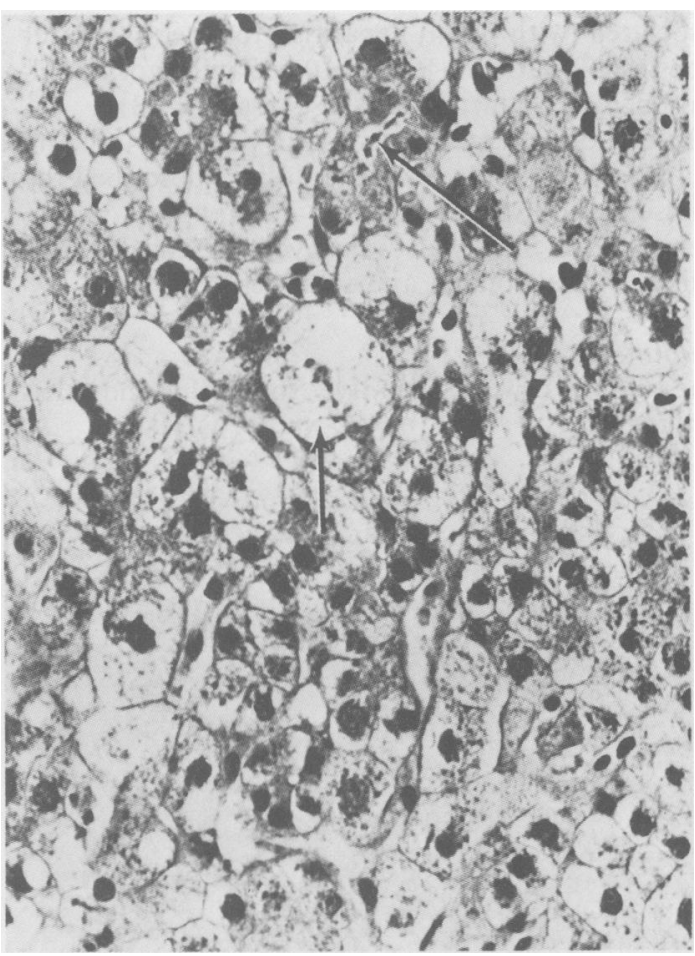

Fig. 2 Patient 1. Acute hepatitis, with swollen hepatocytes (short arrow) and cholestasis (long arrow). Haematoxylin and eosin, $\times 400$ (original magnification).

Table 3 Liver biopsy appearances

\begin{tabular}{|c|c|c|c|}
\hline Patient & $\begin{array}{l}\text { Time from onset } \\
\text { (months) }\end{array}$ & Histological diagnosis & Special features \\
\hline 1 & 5 days & Acute hepatitis & Cholestasis, fat vacuoles, sparse infiltrate \\
\hline 7 & $3 \frac{1}{2}$ & Acute hepatitis & $\begin{array}{l}\text { Heavy infiltrate by monouclear cells in lobules and portal } \\
\text { tracts but liver-cell damage mild }\end{array}$ \\
\hline 6 & 5 & $\begin{array}{l}\text { Acute hepatitis with possible transition to } \\
\text { chronic active hepatitis }\end{array}$ & $\begin{array}{l}\text { Heavy infiltration and both piecemeal and focal necrosis. } \\
\text { Fatty change. Small granuloma. Focal damage to a } \\
\text { small bile duct }\end{array}$ \\
\hline 3 & 7 & Early chronic active hepatitis & $\begin{array}{l}\text { Focal and piecemeal necrosis with periportal fibrosis. } \\
\text { Moderately severe inflammatory infiltration }\end{array}$ \\
\hline 4 & 11 & Chronic persistent hepatitis & Lobular infiltration, fatty change and bile duct damage \\
\hline 8 & 11 & Mild chronic active hepatitis & $\begin{array}{l}\text { Massive mononuclear cell infiltration. Focal and } \\
\text { piecemeal necrosis. Bile duct damage }\end{array}$ \\
\hline 10 & 36 & Chronic persistent hepatitis & $\begin{array}{l}\text { Heavy infiltration by mononuclear cells in lobules and } \\
\text { portal tracts, with lymphoid follicles in latter. Fatty } \\
\text { change }\end{array}$ \\
\hline
\end{tabular}


and periportal inflammation corresponded to that of 'acute hepatitis with possible transition to chronic aggressive hepatitis' described by an international group. ${ }^{12}$

In contrast with these two biopsies, the specimen from patient 3, taken seven'months after onset, showed the balance between liver-cell damage and inflammatory infiltrate more usually associated with viral hepatitis. In the two later biopsies of patients 8 and 10 inflammatory infiltration was again unusually severe (Fig. 3).

Bile duct damage was noted in patients 4,6 , and 8 and corresponded to the lesion described by Poulsen and Christofferson ${ }^{13}$ in that only a segment of bile duct wall was involved, and affected cells were vacuolated and stratified (Fig. 4).

\section{Immunofluorescence}

The biopsies were negative for $\mathrm{HBc}$ and $\mathrm{HBs}$ antigen.

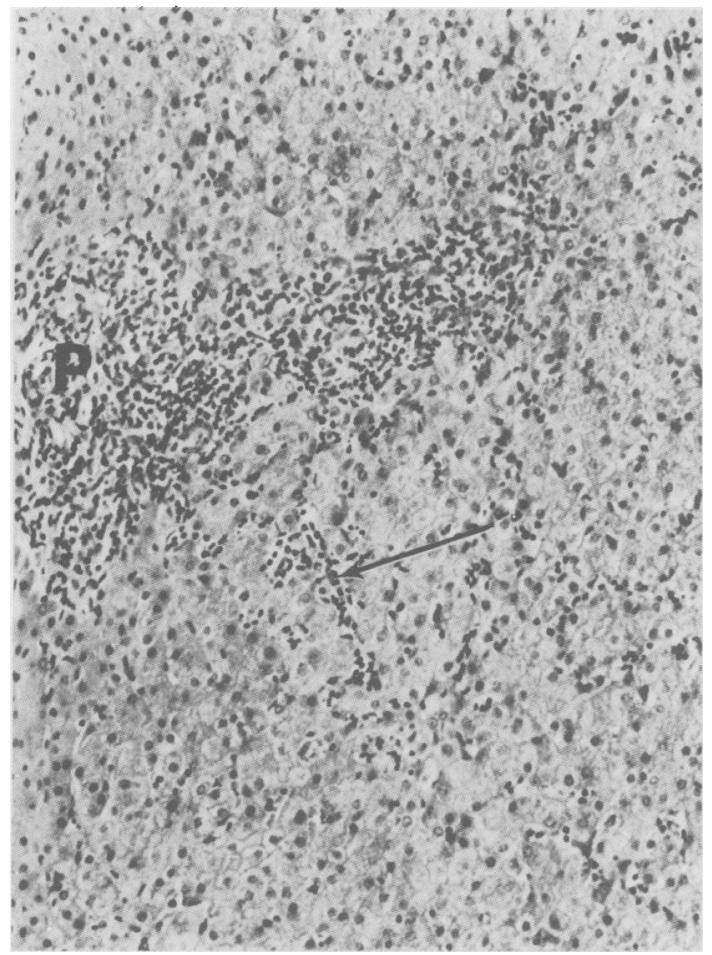

Fig. 3 Patient 8. Chronic active hepatitis. There is a mononuclear cell infiltrate in and around a portal tract $(P)$ and in sinusoids (arrow). $H$ and $E, \times 175$ (original magnification).

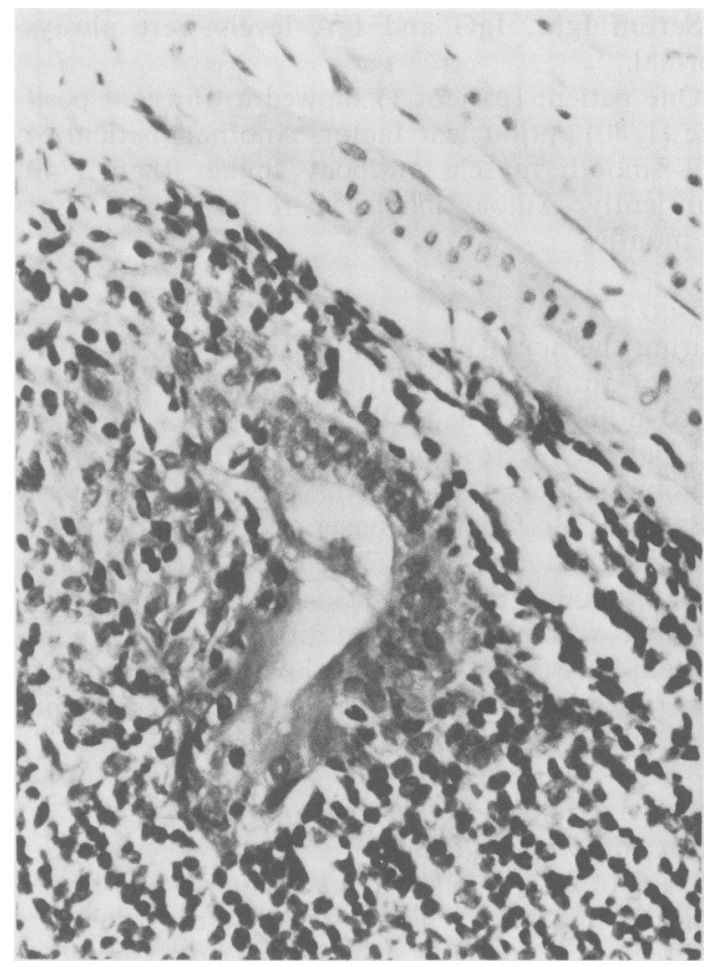

Fig. 4 Patient 8. Damaged bile duct with irregular epithelium, infiltered and surrounded by mononuclear cells. $H$ and $E, \times 405$ (original magnification).

\section{Discussion}

This report describes a group of patients who developed non-A, non-B hepatitis after infusion with factor VIII concentrate or cryoprecipitate. In five of these patients the disease was asymptomatic and anicteric, but in five it was more severe, being associated with nausea, vomiting, and icterus.

Because some patients had received multiple infusions, the identification of the infectious infusate was impossible and incubation period could not be defined. However, in five cases, a single infusion had been administered in the 13 weeks before the development of raised transaminases, and in these cases the incubation period was one to four weeks. This incubation period is similar to that noted in previous reported episodes of nonA, non-B hepatitis in haemophiliac patients ${ }^{1415}$ and chimpanzees ${ }^{5}$ receiving factor VIII concentrates. In five of our cases several infusions had been administered in the three months before the 
onset of the hepatitis, but the interval between the last infusion and the onset of hepatitis was one to four weeks. Because of the similarity of this interval to the established incubation period in the other patients, it seems possible that the last infusion was indeed responsible for transmission of the infectious agent.

Although clinically similar to a previously reported episode of short incubation hepatitis in haemophiliac patients, ${ }^{15} 16$ none of our patients recovered within six months, whereas all those previously reported had done so within a few months. Although this difference may merely be a reflection of small sample size, it may indicate the presence of more than one type of short incubation non-A, non-B hepatitis virus, only one of which has a high rate of induction of chronic liver disease. Another factor relating to chronicity may be repeated infusion of infected material after the onset of hepatitis. This seems unlikely in that three patients who received a single infusion manifested the same clinical and biochemical course as those who received multiple infusions.

The failure of these patients to recover within the period of study (six to 45 months) suggests that this viral agent is an important cause of chronic liver disease in patients with coagulation disorders and possibly also in the general population. Autoantibody formation and raised globulin levels were not seen, so that this type is serologically similar to chronic active liver disease induced by hepatitis $B$ virus but dissimilar to autoimmune chronic active hepatitis.

Liver histology in three patients showed mild or moderate chronic active hepatitis and in two chronic persistent hepatitis. A prominent feature was the intense lobular sinusoidal mononuclear cell infiltration which had previously been noted in chimpanzees with this infection, ${ }^{14}$ and is reminiscent of infectious mononucleosis or cytomegalovirus infection. Other features not commonly associated with viral hepatitis included fatty change (patients 1, 4, and 10), a small granuloma (patient 6), and damaged bile ducts (patients 4, 6, and 8). The long-term significance of the chronic changes that were observed cannot be assessed on histological grounds, as there is no precedent on which to base prognostic judgements. Follow-up, both clinical and histological, will be needed to establish the natural history of this disease.

M Bamber, A Murray, and H C Thomas were supported by the MRC. H C Thomas also received support from the Wellcome Trust, as did BAM Arborgh.

\section{References}

${ }^{1}$ Alter MJ, Purcell RM, Holland PV. Clinical and serological analysis of transfusion associated hepatitis. Lancet 1978; 2:838-41.

2Dienstag JL, Alaama A, Mosley JW, Redeker AG, Purcell RM. Etiology of sporadic hepatitis B surface antigen negative hepatitis. Ann Intern Med $1977 ; 87: 1-6$.

${ }^{3}$ Mosley JW, Redeker AG, Feinstone SM, Purcell RM. Multiple hepatitis viruses in multiple attacks of acute viral hepatitis. N Engl J Med 1977; 296: 75-8.

${ }^{4}$ Wyke RJ, Tsiquaye KN, Thornton A, et al. Transmission of non-A, non-B hepatitis to chimpanzees by factor IX concentrates after fatal complications in patients with chronic liver disease. Lancet 1979; 1:520-4.

${ }^{5}$ Tsiquaye KN, Zuckerman AJ. New human hepatitis virus. Lancet 1979; 1:1134-6.

${ }^{6}$ Shimizu YK, Feinstone SM, Purcell RM, Alter HJ, London WT. Non-A, non-B hepatitis: ultrastructural evidence for two agents in experimentally infected chimpanzees. Science 1979; 205:197-200.

7Jackson D, Tabor E, Gerety RJ. Acute non-A, nonB hepatitis: specific ultrastructural alterations in endoplasmic reticulum of infected hepatocytes. Lancet 1979; 1:1249-50.

${ }^{8}$ Shirachi R, Shiraishi H, Tatada A, Kikuchi K, Ischida $N$. Hepatitis ' $C$ ' antigen in non- $A$, non-B post transfusion hepatitis. Lancet 1979 2:853-6.

${ }^{9}$ Vitvitski L, Trepo C, Prince AM, Brotman B. Detection of virus associated antigen in serum and liver of patients with non-A, non-B hepatitis. Lancet 1979; 2:1263-7.

${ }^{10}$ Suh DJ, White Y, Eddleston ALWF, et al. Specificity of an immunoprecipitin test for non-A, non-B hepatitis. Lancet $1981 ; 1: 178-80$.

${ }^{11 B r a d l e y ~ D W, ~ M a y n a r d ~ J E . ~ S e r o d i a g n o s i s ~ o f ~ v i r a l ~}$ hepatitis A by radioimmunoassay. Lab Management 1978; 2:29-34.

12 International Group. Morphological criteria in viral hepatitis. Lancet $1971 ; 1: 333-7$.

13Poulsen H, Christofferson P. Abnormal bile duct epithelium in liver biopsies with histological signs of viral hepatitis. Acta Pathol Microbiol Scand $[B]$ 1969; 76:383-90.

${ }^{14}$ Alter HJ, Purcell RM, Holland PV, Popper $\mathrm{H}$. Transmission agent in non-A, non-B hepatitis. Lancet 1978; 1:459-63.

${ }^{15}$ Hruby A, Schauf V. Transfusion related short incubation hepatitis in haemophiliac patients. JAMA 1978; 240:1355-7.

${ }^{16}$ Craske J, Dilling N, Stern D. An outbreak of hepatitis associated with intravenous injection of factor VIII concentrate. Lancet 1975; 2:221-3. 